University of Wollongong

Research Online

Faculty of Law, Humanities and the Arts Papers (Archive)

$1-1-2018$

Servant mobilities between Fiji and New Zealand: The transcolonial politics of domestic work and immigration restriction, c.1870-1920

Frances Steel

University of Wollongong, fsteel@uow.edu.au

Follow this and additional works at: https://ro.uow.edu.au/lhapapers

Part of the Arts and Humanities Commons, and the Law Commons

Research Online is the open access institutional repository for the University of Wollongong. For further information contact the UOW Library: research-pubs@uow.edu.au 


\title{
Servant mobilities between Fiji and New Zealand: The transcolonial politics of domestic work and immigration restriction, c.1870-1920
}

\author{
Abstract \\ In the late nineteenth and early twentieth centuries, Europeans travelling beyond Fiji were often \\ accompanied by Melanesian, Indian or Indigenous Fijian servants. Occasionally, families resident in the \\ Australasian settler colonies also hired servants, mostly men, from Fiji. This article traces such patterns \\ of transcolonial domestic labour mobility, and highlights instances of servants challenging employer \\ controls and seeking out more autonomous futures. Viewed together, these fragmentary histories \\ suggest possibilities for juxtaposing and integrating temporary, short-term and circular transcolonial \\ mobilities that tend to be overlooked in nation-centred histories of immigration and colonial domesticity. \\ Disciplines \\ Arts and Humanities | Law

\section{Publication Details} \\ Steel, F. (2018). Servant mobilities between Fiji and New Zealand: The transcolonial politics of domestic \\ work and immigration restriction, c.1870-1920. History Australia, 15 (3), 519-539.
}


Servant Mobilities between Fiji and New Zealand: The Transcolonial Politics of Domestic Work and Immigration Restriction, c.1870-1920

Frances Steel

School of Humanities and Social Inquiry

University of Wollongong

Northfields Avenue

NSW 2500

fsteel@uow.edu.au

ORCiD: 0000-0001-7240-1530

\begin{abstract}
In the late nineteenth and early twentieth centuries, Europeans travelling beyond Fiji were often accompanied by Melanesian, Indian or indigenous Fijian servants. Occasionally, families resident in the Australasian settler colonies also hired servants, mostly men, from Fiji. This article traces such patterns of transcolonial domestic labour mobility, and highlights instances of servants challenging employer controls and seeking out more autonomous futures. Viewed together, these fragmentary histories suggest possibilities for juxtaposing and integrating temporary, short-term and circular transcolonial mobilities that tend to be overlooked in nation-centred histories of immigration and colonial domesticity.
\end{abstract}

Keywords

Australasia, Domestic service, Indian servants, Melanesian servants, transcolonial mobility

When Rodney Acraman, a 'part European' (the prevailing term in Fiji for those of mixed descent), was interviewed in the late 1990s for the Fiji Oral History project he recalled an incident in his early life that still made him wince with discomfort. On returning to his family home in Fiji in the 1950s during his holidays as a student of law at the University of 
Auckland, his mother told him that before going to church he should get the house servant to clean his shoes. Acraman found this experience so embarrassing and disagreeable, and worlds apart from the life he had grown accustomed to in New Zealand, that he offered the man a tip. Later, when he returned to Fiji to take up a government appointment, he refused to have servants and was told he was being 'very miserly' and he 'should help by employing people'. Acraman eventually succumbed, but was proud to note that over the following thirty-five years he had just two servants, for 'you look after them, you know?', and invariably they 'stayed on, and on, and on'.'

Acraman's reflections epitomise the distinctions typically drawn between the domestic relations at the heart of different colonial formations. British households in temperate, settler-dominated colonies like New Zealand upheld a tradition of resourcefulness and 'making do'. Many people may have aspired to employ servants, but the dominant preference for white single women could not be met through systematic colonisation from Britain. In the face of acute labour shortages, white women shouldered additional burdens of household management unknown to many of their middle-class counterparts in Britain, gradually fashioning a colonial ideal of the 'servant-free' household. ${ }^{2}$ In tropical colonies

\footnotetext{
${ }^{1}$ Rodney Acraman (9 March 1999), PMB Audio 26-7, Fiji Oral History Project 1998-99, sponsored by the Fiji Museum and the Pacific Manuscripts Bureau. Acraman was the first 'part European' to graduate with an LLB. His heritage was French, English, American, Samoan and Fijian. He was aged 66 at the time of the interview.

2 Jane McCabe, 'Settling In, From Within: Anglo-Indian “Lady-Helps” in 1920s New Zealand', in Colonization and Domestic Service: Historical and Contemporary Perspectives, eds Victoria K. Haskins and Claire Lowrie (New York: Routledge, 2015), 65; Charlotte Macdonald, 'Strangers at the Hearth: The Eclipse of Domestic Service in New Zealand
} 
such as Fiji, where white settlers were never demographically dominant, European households could draw on imported colonial labour typically diverted from plantation indenture, and often also relied upon indigenous people. Servants, most of whom were men, performed a range of domestic duties, and their white mistresses assumed the additional responsibilities of employer, supervisor and 'civilising' influence. ${ }^{3}$ This in itself was a marker of status, and the wealthier and larger the home, the more extensive the available assistance.

These are, of course, stylised distinctions and easily blurred. In many settler colonies, indigenous men and women, as well as immigrant labourers, were employed as servants in white homes. In tropical colonies, many white householders struggled to secure the desired domestic help and had to learn to do without. And while Acraman's reflections centre his own mobility to cast the connective and comparative light on domesticity in Fiji and New Zealand, servants were also frequently on the move in colonial history.

In this article I focus on instances of servant mobility from the British colony of Fiji to New Zealand in the late-nineteenth and early-twentieth centuries. Suva, Fiji's colonial capital, increasingly served as a labour hub from where domestic servants - Melanesian, Indian, and less often indigenous Fijian - accompanied their Fiji-based European employers on extended periods of travel or residence overseas, often to the Australasian colonies. In a small number of cases, they were also recruited to serve families who resided in New Zealand Homes c.1830s-1940s' in At Home in New Zealand: Houses, History, People, ed. Barbara Brookes (Wellington: Bridget Williams Books, 2000), 44.

${ }^{3}$ Claudia Knapman, White Women in Fiji 1835-1930: The Ruin of Empire? (Sydney: Allen and Unwin, 1986); Claudia Knapman, 'Reproducing Empire: Exploring Ideologies of Gender and Race on Australia's Pacific Frontier', in Debutante Nation: Feminism Contests the 1890s eds, Susan Magarey, Sue Rowley and Susan Sheridan (Sydney: Allen \& Unwin, 1993), 12535. 
or Australia. These mobilities, I hope to demonstrate, offer new insights into relations across the colonial 'sisterhood' of British Australasia, of which Fiji was an integral, if frictionproducing part. Furthermore they serve to muddy the conceptual distinctions that have traditionally demarcated histories of temperate/tropical and settler/extractive colonialisms in the Pacific and beyond. ${ }^{4}$

In the nineteenth century the term 'Australasia' designated the interlinked territories under British imperial control in the South Pacific. ${ }^{5}$ Following the decline of the Victorian and Otago gold rushes and the outbreak of war in northern New Zealand in the 1860s, many recent British immigrants remigrated to Fiji, enticed by agricultural prospects, particularly as American cotton production plummeted during the Civil War. ${ }^{6}$ Britain annexed the island group in 1874 as a crown colony. It never envisaged Fiji as a ‘white man's country', but encouraged the development of sugar plantations and instigated a scheme of Indian indenture from 1879. The Australian Colonial Sugar Refinery Company (CSR) was encouraged to

\footnotetext{
${ }^{4}$ Scholarship addressing such historiographic divisions has more readily placed India and the white settler colonies in the same analytic frame, whether by examining circuits of ideas or by tracing subaltern mobilities. See, for example, Tony Ballantyne, Orientalism and Race: Araynism in the British Empire (Basingstoke: Palgrave, 2002); Deana Heath, 'Comparative Colonialism, Moral Censorship and Governmentality', in Durba Ghosh and Dane Kennedy, eds, Decentring Empire: Britain, India and the Transcolonial World (New Delhi: Orient Longman, 2006); Devleena Ghosh, 'Under the Radar of Empire: Unregulated Travel in the Indian Ocean', Journal of Social History 45, no. 2 (2011): 497-514.

${ }^{5}$ Donald Denoon, 'Re-membering Australasia: A Repressed Memory', Australian Historical Studies 34, no. 122 (2003): 290-304.

${ }^{6}$ John Young Adventurous Spirits: Australian Migrant Society in Pre-Cession Fiji (St. Lucia, Qld: University of Queensland Press, 1984).
} 
expand its operations to Fiji. Although Sydney would dominate general trade with Fiji, New Zealand frequently asserted its desire to secure exclusive economic and political relations with the island group, which it perceived as a favourable gateway to the eastern Pacific. A monthly steamship service from Auckland in 1881 augmented existing schooner connections, and various New Zealand firms began to establish agencies and branches, particularly in Levuka, Suva and Lautoka. ${ }^{7}$

Movement between Fiji and the southern settler colonies was relatively free throughout the 1870s and 1880s. Towards the end of the century, however, colonial officials at both ends closely scrutinised the mobility of non-white subjects, even as New Zealand continued to agitate for the formal political incorporation of Fiji, a point I return to later. Despite tighter controls, the circulation of people meeting short-term or temporary labour demands, including for domestic service, continued. Yet, perhaps because many servants arrived in New Zealand from Fiji accompanying their employers, rather than necessarily to serve masters and mistresses in New Zealand, their presence has fallen further through the gaps of nation-centred histories of both colonial domesticity and immigration restriction. This focus on servants helps to illuminate some of the 'little-known lives' in colonial New Zealand, as Sean Mallon has remarked with reference to Pacific Islanders. Fiji, a prominent hinge point or meeting-place where cultural influences across the Indian and Pacific ocean worlds converged, offers a unique vantage point to engage the overlapping trajectories of Asian as well as Islander labourers in New Zealand. ${ }^{8}$ In doing so, I seek to raise new

\footnotetext{
${ }^{7}$ See also Frances Steel, Oceania Under Steam: Sea Transport and the Cultures of Colonialism, c.1870-1914 (Manchester: Manchester University Press, 2011).

${ }^{8}$ Sean Mallon, 'Little-Known Lives: Pacific Islanders in Nineteenth Century New Zealand', in Tangata o le Moana: New Zealand and the People of the Pacific, eds Sean Mallon,
} Kolokesa Māhina-Tuai and Damon Salesa (Wellington: Te Papa Press, 2012). For the Indian 
questions about the relationship between transcolonial mobilities and community formation, and thereby reconnect New Zealand to a wider, transoceanic imperial sphere.

In New Zealand there was "no answer to the "servant problem"”, as Charlotte Macdonald has recently explored. Intermittent attempts to recruit Māori women and men as house servants were not successful. Only a state-sponsored recruitment and immigration scheme would meet settler demands, but New Zealand did not look beyond Britain for servants. The main reasons, as Macdonald argues, centred on race and the heightened emphasis on preserving a 'white New Zealand', a colour line drawn 'as much at New Zealand doorsteps and kitchen tables as it was in houses of Parliament, immigration offices or prestigious London conferences'. ${ }^{9}$ I seek to prise open episodes where recruitment from the proximate tropics did occur. The broader rejection of 'race subordination' that underpinned these models of colonial domestic service, I want to suggest, also emerged out of embodied, often fraught, if only short-lived, relationships on New Zealand soil, rather than an a priori cultural rejection of such relationships. Once in New Zealand, servants recruited from Fiji not infrequently challenged the constraining and often unreasonable expectations of employers, sometimes through violence, but more often through the courts. A small number, as I go on to discuss, were able to carve out more independent means and futures, albeit in the context of a tightening world of white settler nationalism in the first decades of the twentieth century.

Ocean influence in attitudes towards domestic labour in northern Australia, see Julia Martinez, 'Asian Servants for the Imperial Telegraph: Imagining North Australia as an Indian Ocean Colony Before 1914', Australian Historical Studies 48, no. 2 (2017): 227-43. ${ }^{9}$ Charlotte Macdonald, 'Why Was There No Answer to the "Servant Problem"? Paid Domestic Work and the Making of a White New Zealand, 1840s-1950s', New Zealand Journal of History 51, no. 1 (2017): 9-10. 
It should be noted that the importation of labour from other parts of the British Empire was in fact at times perceived as a partial solution to the chronic servant shortage in New Zealand. Jane McCabe has examined the resettlement from 1909 of 130 adolescents from India, the children of European tea-planter fathers and Indian mothers. Domestic work, notably for the young women, was framed as a pathway to eventual integration into the settler colony. Anxieties about their mixed-race status and future prospects were far less pronounced, or at least different, than in India. ${ }^{10}$ Macdonald and Rosemary Anderson have both focused on a later period, from World War II onwards, as New Zealand looked within its own empire, recruiting women from the Cook Islands on short-term domestic service contracts. Unlike those resettled from India, it was expected that these women would return home. Yet their British status effectively ensured this could not be enforced, and many used the labour scheme as a route to permanent migration to New Zealand. ${ }^{11}$

Employers involved in the Cook Islands scheme often stressed racial preferences, including the hope that Chinese might be available, and referred to 'housegirls' and 'houseboys', rather than 'lady-helps' or 'companions' frequently used for Anglo-Indian servants. While such terminology may have marked 'a sharp departure' from the prevailing relations of domestic service, ${ }^{12}$ there were also earlier instances of employers adopting wider imperial attitudes about 'ideal' servants to the settler colony. But like the Anglo-Indian and

${ }^{10}$ Jane McCabe, 'Settling In, From Within'; McCabe, Race, Tea and Colonial Resettlement: Imperial Families, Interrupted (London: Bloomsbury, 2016).

${ }^{11}$ Charlotte Macdonald, 'Taking Colonialism Home: Cook Island "Housegirls" in New Zealand, 1939-1948', in Colonization and Domestic Service, 273-88; Rosemary Anderson, 'Distant Daughters: Cook Islands Domestics in Wartime New Zealand, 1941-46', Journal of Pacific History 48, no. 3 (2013): 267-85.

${ }^{12}$ Macdonald, 'Taking Colonialism Home', 277. 
Cook Island schemes, state concerns about duration and 'permanence' would also overshadow and constrain servant pathways from Fiji to New Zealand.

\section{Male domestic service in early colonial Fiji}

Acraman's recollections normalised the figure of the non-white servant in Fiji's midtwentieth-century European (and 'part-European') homes, yet there was arguably little in the early period of British rule to foreshadow this outcome. Officials often brought servants with them to new postings in the Pacific. Fiji’s first governor, Sir Arthur Gordon, appointed in 1875 after positions in Mauritius and Trinidad, imported a 'Hindoo' cook and two 'Hindoo valets'. Staff at Government House also comprised Fijian servants and 'labour-boys of every colour and nation', including a Spanish washerman. ${ }^{13}$ Alfred Maudsley, an assistant to Gordon, arrived with his 'negro boy' whom he had engaged in Trinidad. ${ }^{14}$

The colony's first chief justice, John Gorrie, struggled to procure servants during his five-year tenure. He eventually obtained a cook, 'a Madrasee', who arrived in Fiji after time spent in Mauritius, Réunion and New Caledonia, 'so he speaks French', as Gorrie's twentyyear-old daughter, Minnie, recorded. ${ }^{15} \mathrm{He}$ came to the colony in the service of a European

${ }^{13}$ Constance Gordon Cumming, At Home in Fiji (Edinburgh: William Blackwood and Sons, 1882), 147-8, 182.

${ }^{14}$ Alfred Percival Maudsley, Life in the Pacific 50 Years Ago (London: George Routledge \& Sons Ltd, 1930), 59.

${ }^{15}$ Minnie Gorrie, Diary, 30 June 1878, MSX 7771, Alexander Turnbull Library Wellington (ATL). For the history of indenture from the Indian Ocean colonies to New Caledonia, see Karin Speedy, 'Who Were the Reunion "Coolies” of 19th-Century New Caledonia?' Journal of Pacific History 44, no. 2 (2009): 123-40; K.L. Gillion, 'The Sources of Indian Emigration to Fiji’, Population Studies 10, no. 2 (1956): 139-57. 
man from Ceylon. When this employer refused him an advance of wages and provided only yams to eat, he broke contract and aligned himself to Gorrie. He stayed only a few months, as Minnie recorded, 'said he wanted to go back to Sydney - so Papa told him he might. It is such a horrid nuisance'. ${ }^{16}$ This man's mobility was indicative of the circuits traversed not only by colonial officials, but also the people who supported their imperial 'careering'. Yet his experiences also at least hint that improved shipping enabled some people independent access to means of mobility to test better prospects over the horizon. In the Gorrie household the burden of cooking ultimately fell to Minnie, her mother paying her the wages reserved for a cook: 'It will be the first money I ever earned'. At other times they resorted to borrowing servants from other families, including of guests invited to dinner. Minnie continued to hope that 'a cargo of cooks' would arrive in Fiji, as she found the work 'horrible'. When her father eventually accepted a new posting to the Leeward Islands in the West Indies, Minnie reflected that 'surely in no other place would we have our own cooking to do' ${ }^{17}$ Here, the lack of servants revealed other possibilities for colonial economies of domestic labour, yet regardless of the wage, such work was perceived as especially diminishing for white women. Kitchen labour interfered with the more leisured and genteel domestic roles of hostess and conversationalist, expectations that underpinned notions of feminine propriety (and such activities, along with private study, otherwise fill Minnie's diary). The difficulty in securing servants also confronted wealthy settlers in mid-nineteenth-century New Zealand, yet most

\footnotetext{
${ }^{16}$ Minnie Gorrie, Diary, 22 September 1878, MSX 7771, ATL.

${ }^{17}$ Minnie Gorrie, Diary, 17 March 1878, 22 October 1882, MSX 7771, ATL.
} 
white women ultimately shouldered greater (unpaid) domestic burdens out of necessity until many came to relish a 'purposeful and satisfying independence'. ${ }^{18}$

Common settlers in Fiji faced greater obstacles and competed with one another for servants. Casual engagements of Fijian men (and sometimes women) characterised the immediate pre-cession decades, but servants were soon recruited from the pool of labourers brought to Fiji under plantation indenture. ${ }^{19}$ Following British annexation, Gordon was intent on 'preserving' the indigenous race, and regulated, but never terminated, the employment of Fijian men on plantations. Indian indenture augmented the existing channels of indentured labour from the Solomons and New Hebrides, which paralleled those to Queensland's sugar plantations. A small number of Indian men and women from each 'coolie ship' were diverted to work in private homes. Thus of the 498 men, women and children on the first ship, the Leonidas, in 1879, about twenty were sent as servants to Levuka, the main European settlement at that time. The following year, a European couple was prosecuted for assaulting two servants assigned to them. ${ }^{20}$

The CSR operated in Fiji from 1880. In its first four decades the company built mills and organised the cultivation of sugar cane, leasing its estates to planters or contracting with

\footnotetext{
${ }^{18}$ Macdonald, 'Why Was There No Answer to the "Servant Problem”?', 14. Knapman argues that in colonial Fiji paid domestic work was off limits to white women of all social classes, because, as on plantations, 'labourers were black', see 'Reproducing Empire', p.128 ${ }^{19}$ Some of what follows in this section is drawn from chapters 2 and 6 in Julia Martinez, Claire Lowrie, Frances Steel and Victoria Haskins, Colonialism and Male Domestic Service across the Asia Pacific (London: Bloomsbury, in press 2018).

${ }^{20}$ William Seed to Colonial Secretary, 25 August 1880, 80.156, Colonial Secretary's Office minutes (CSO), National Archives of Fiji (NAF).
} 
growers settled on their own land. ${ }^{21}$ CSR officers and white supervisory staff were typically allotted Indian servants as part of their domestic allowance (which included salary and quarters, with managers and overseers supplied with furnished houses). Indian men were selected from the pool of indentured labour and trained up as 'houseboys' on the estates.

Settler demand for domestic labour, largely from the plantations but also in urban areas, was so high that the Agent-General of Immigration, Henry Anson, remarked that on first assuming office in 1882 'it was little better than a Registry for servants'. ${ }^{22} \mathrm{He}$ was petitioned to recruit trained servants directly from India, colonists pointing to the failure of attempts to train indentured men for domestic work. ${ }^{23}$ Petitioners were informed that immigrant ships were for the importation of agricultural labour only. ${ }^{24}$ Officials suggested colonists approach a Calcutta agency in a private capacity, yet recruiters there advised that 'no good servant would recruit in the way which an ordinary Coolie does'. Fiji might instead follow the example of British Guiana and Trinidad, where local-born children of emigrants were trained as 'fair house servants'. ${ }^{25}$ Yet many colonists insisted on a different class of

${ }^{21}$ Bruce Knapman, 'The Rise and Fall of the White Sugar Planter in Fiji, 1880-1925', Pacific Studies 9, no. 1 (1985): 53-82; Michael Moynagh, Brown or White? A History of the Fiji Sugar Industry, 1873-1973 (Canberra: Australian National University, 1981).

${ }^{22}$ Anson, 30 August 1887, 87.1983, CSO, NAF.

${ }^{23} 24$ October 1883, 83.2822, 17 March 1884, 84.592, CSO, NAF.

${ }^{24} 29$ March 1884, 84.592, CSO, NAF.

${ }^{25}$ Fiji Government Emigration Agency, Calcutta to Agent General of Immigration, Fiji, 27 May 1885, 85.2102, CSO, NAF. 
people 'from the ordinary immigrant' - typically identified as 'Madrasses' [sic], with servants from Madras widely favoured as the 'best' in India. ${ }^{26}$

Time-expired plantation workers who took up informal positions as servants in European homes had to contend with employers' exploitation of notions of racial subordination and the low esteem in which they held such work. Anson outlined his reservations, here with closer reference to Solomon Islanders, who were initially more widely employed than Indians or Fijians. He noted cases of abuse where employers tipped pails of excrement over their servants, and did 'all kinds of nasty unfair and cruel things ... which no person would attempt if the bond of union between master and servant was one of mutual satisfaction'. ${ }^{27}$

A Masters and Servants Ordinance came into force in Fiji in 1890. As the wider literature on Masters and Servants laws makes clear, their main aim was to restrict or regulate the mobility of workers between employers and occupations. ${ }^{28}$ In the Fijian domestic context, contracts longer than one month had to be formalised before a magistrate. No contract could be longer than twelve months and both parties were free to dissolve the agreement by advance warning. Servants were to be paid in cash at the end of each month and the employer was required to provide food, lodging and medical care. Contracts with indigenous Fijian servants involved additional regulations to enable them to fulfil family and provincial

${ }^{26}$ 85.2102, CSO, NAF; Edmund C.P. Hull, The European in India, or Anglo-Indian's Vademecum (London: Henry S. King \& Co., 1871), 119.

2730 August 1887, 87.1983, CSO, NAF.

${ }^{28}$ 'Atu Bain, ‘A Protective Labour Policy? An Alternative Interpretation of Early Colonial Labour Policy in Fiji', Journal of Pacific History, 23, no. 2 (1988), 119-36. More generally, see Douglas Hay and Paul Craven, eds, Masters, Servants and Magistrates in Britain and the Empire, 1562-1955 (Chapel Hill: University of North Carolina Press, 2004). 
obligations, such as building houses or canoes, planting gardens and fishing. ${ }^{29}$ No wage scale was laid down by law and payment was negotiated on a case-by-case basis. In the early 1890 s the standard wage in Fiji was five shillings per week (£1 a month) plus keep. Indians were preferred, particularly as cooks and laundrymen, and were always paid more than Pacific Islanders..$^{30}$

I pause at this point to consider the marked preference for male servants. The 1876 Native Labour Ordinance prohibited Fijian women leaving their villages to seek paid employment. ${ }^{31}$ Later in the century an official report on depopulation reinforced representations of indigenous women as central to stabilising and preserving the 'traditional' way of life in rural communities, a status at odds with working long hours with little autonomy in European homes. Fijian, as well as indentured Melanesian women, sometimes worked as servants, Indian women far less often, but in general colonial employers appear to have preferred male servants for a very 'modern' reason, i.e. that women were unreliable

\footnotetext{
${ }^{29}$ No.1 of 1890: An Ordinance Relating to Masters and Servants, The Ordinances of the Colony of Fiji (Suva: Government Printer, 1914). Unlike the Fijian Labour Ordinances
} governing plantation indenture, the consent of village and district chiefs was not required, nor did the 1890 Ordinance place limits on working hours or stipulate overtime. Because of these and other 'trifling' safeguards, plantation owners preferred to (illegally) recruit Fijians under the Masters and Servants Ordinance, see Bain, 'A Protective Labour Policy'.

30 ‘Our Fiji Letter', Otago Daily Times, 25 February 1893, 5.

${ }^{31}$ In 1883 all women were prevented from entering labour contracts, Bain, 'A Protective Labour Policy?', 123. 
because of responsibilities to or in their own families (rather than, say, concern for sexual intimacies with European men more commonly evoked in other colonial contexts). ${ }^{32}$

There are no available employment figures for the 1880-1910 period discussed in this article, for the Fiji Census recorded occupations for the first time only in 1911. In that year 205 Fijian men and 52 women worked as cooks and domestics, and 314 Indian men and 35 women. This represented a tiny proportion of the total population (when classified by race, this amounted to $0.12 \%$ Indian men and boys and $0.04 \%$ Fijians). ${ }^{33}$ In New Zealand, where the employment of female domestics was in decline from the 1880s, the 1911 Census recorded $623(0.11 \%)$ men and 19,421 (3.8\%) women engaged as domestic servants, ladyhelps and companions. ${ }^{34}$ Thus, for every 100 servants in New Zealand (using 1911 figures), 97 were women and 3 men, while in Fiji 83 were men and 17 women. Although outside the scope of this discussion, the proportion of women in domestic service increased in Fiji in the 1930 s, and 'housegirls' would soon dominate in the postwar period. ${ }^{35}$

${ }^{32}$ For more on questions of gender, see Martinez et al, Colonialism and Male Domestic Service, esp. chapter 2.

${ }^{33}$ Legislative Council Fiji, Census, 1911, Council Paper No. 44 (1911).

${ }^{34}$ Results of a Census of the Dominion of New Zealand, https://www3.stats.govt.nz/historic_publications/1911-census/1911-results-census.html (last consulted 18 February 2018). For more on downwards trends from 1880s, see Macdonald, 'Strangers at the Hearth'.

${ }^{35}$ Interestingly, the 1916 Census of New Zealand was the only one to categorise workers by race, and its snapshot of domestic service conformed to the broader imperial pattern: 305 non-white men and only 22 women were employed in this capacity. This included 284 Chinese men; 8 'Hindus', 4 Syrians, 9 'Others'; and 6 Chinese women, 5 'Hindus' and 9 Others, https://www3.stats.govt.nz/historic_publications/1916- 


\section{Travelling servants}

Even before the passage of the 1890 ordinance in Fiji, settlers and officials routinely travelled beyond the colony with their servants in tow, whether to neighbouring settlements in Tonga and Samoa, where it was harder to procure domestic labour, to the Australasian colonies, or further afield, including to India and Britain. ${ }^{36}$ Permission to take servants was granted on the grounds of 'special circumstances', usually to accompany a settler in ill-health or during a short-term visit, although some took servants for lengthier terms to new administrative postings or jobs in other islands. Employers were typically required to lodge a bond of $£ 50$ for the individual's safe and timely return. Those passing through Suva to other parts of the Pacific might view the port as a place to hire domestic labour. For instance, Fanny van de Grift Stevenson, the wife of Robert Louis Stevenson, engaged an Indian servant, Abdul Ruzzak, to accompany her to Samoa. Ruzzak was one of the few men privately recruited directly from India to Fiji, having been released from his employment at the Bengal Club to serve as butler to Fiji's Attorney General, John Udal. ${ }^{37}$

Colonial officials, who recorded consulting servants as to their wishes before granting permission to travel, invariably noted that they were 'anxious' or 'eager' to go. Servants were liable to be mistreated during their absence, and it was not uncommon for family members to seek assurances from officials of their whereabouts and well-being. Once overseas, settler requests for extensions of absence were often refused on the grounds that officials in Fiji had

census/Report $\% 20$ on $\% 20$ Results $\% 20$ of\%20Census $\% 201916 / 1916$-report-results-

census\%20.html (last consulted 18 February 2018).

${ }^{36}$ For instance $87.1182 ; 87.3016$, CSO, NAF.

3730 September 1891, and ensuing commentary, 91.3623, CSO, NAF. 
no way of gauging the servants' wishes. ${ }^{38}$ It is clear that both Melanesian and Indian servants suffered on account of the colder climate, especially in New Zealand, and some chose to return to Fiji before their employers. These individuals, first indentured to Fiji, confronted new stresses in the neighbouring colonies, where their presence was more readily framed as anomalous and unsettling, if not unwelcome. One of the more high-profile cases indicated the strain of this 'double displacement' might be deeply affecting.

In 1880, the Wilcotts, a planter family on the Ba River in Fiji, resided in Auckland for a number of weeks to arrange a consignment of sheep. They were accompanied by their servant Joe, who had been with the family since 1871 . Referred to in the press as 'Joe the Fijian', he was in fact indigenous to Api in the New Hebrides and previously indentured to Fiji. One evening, about a month after arriving in Auckland, Joe attacked one of the Wilcott children with an axe (a child whom he had nursed in infancy), and, upon fleeing the home, killed an unrelated man in the street and injured another woman. During his trial for murder, Joe explained his actions through an interpreter: 'I stopped nicely in this town, and was treated well, and no white man ever beat me. I am not stupid or silly. The root of this mischief was derived from Fiji', alluding to the psychological strain of indenture. But he went on to state that the boy's father, Edward Wilcott, had recently scolded him for failing to complete housework, and Wilcott's friend told him 'the whites would hang me to a beam'. He brooded over the insult, and two days later grew enraged when the children taunted him, saying 'the Maoris would come and cut my hands off, and put the ends of me in the fire' ${ }^{39}$ Edward Wilcott denied this account, but recalled Joe's two prior 'fits of mental derangement' in Fiji, one of which occurred during the measles epidemic that devastated the islands in

\footnotetext{
3817 November 1881, 81.2174, and 17 January 1882, 82.303, CSO, NAF.

39 ‘The Fijian Murderer and His Victims', New Zealand Herald, 30 September 1880, 5.
} 
1875 , 'but as some other islanders were the same way', Wilcott remarked, 'he thought nothing of it'. He otherwise stressed Joe's usual gentle nature and loyal behaviour. ${ }^{40}$

Newspaper reports attributed the attack not to Joe's personal trauma, but innate 'murderous' traits, denouncing him as a 'human tiger' who acted like 'a wild beast' ${ }^{41}$ The incident prompted wider denunciations of New Hebridean islanders, in light of the continuing violence of the Pacific labour trade frequently reported in the colonial press and in which New Zealand-based crew and vessels were often implicated. Such violence, when perpetrated by Europeans, was legitimised as pre-emptive or defensive, the necessary response to 'savagery' along the recruitment frontiers, or what Tracey Banivanua Mar delineated as the Pacific's 'heart of darkness'. ${ }^{42}$ Whereas Wilcott stressed his confidence in Joe as a longserving member of the family, in such reports Joe appeared to embody the spectre of such darkness penetrating the settler colony. This demanded constant vigilance, the Auckland Star opined, for it behove any European who engaged such men as house servants 'to always keep an eye on them. They are never, to judge from all accounts, to be trusted' ${ }^{43}$

While the press reports stressed animalistic traits, with associations of overwhelming physical power and connotations of simmering sexual aggression, employers could hardly justify the wilful recruitment of 'savages' to serve in their own homes, caring for children and in close contact with white women. They needed to reimagine notions of primitivism, removed from the lawless frontier and allied to the white household, so as to render such men

\footnotetext{
${ }^{40}$ New Zealand Times, 1 October 1880, 3.

${ }^{41}$ Evening Post, 1 October 1880.

42 Tracey Banivanua Mar, Violence and Colonial Dialogue: The Australian-Pacific

Indentured Labor Trade (Honolulu: University of Hawai'i Press, 2007), 20.

43 'Character of New Hebrides Natives', Auckland Star, 29 September 1880, 3.
} 
suitable 'houseboys'. ${ }^{44}$ Yet there was always an available discourse of sliding savagery, where the dark 'undercurrent' of Melanesia might make itself felt and justify the magnification of a threat. ${ }^{45}$ In this case, Joe's actions were used to denounce other Islanders, notably the resident Fijian community in Auckland. The New Zealand Times asserted that 'people are aghast at the danger in their midst', and demanded an urgent enquiry into the number of Fijians in the colony, the circumstances under which they arrived, 'the extent of control exercised over their actions, and what precautions are taken against influences exciting their savage instincts'. ${ }^{46}$

These Fijian men, who numbered around forty, were brought to New Zealand by former island planters and traders, circumstances different to the more well-documented pathways for education, the church or maritime industries. ${ }^{47}$ Some of them worked in stores, while others for wealthy households, with the Otago Daily Times now denouncing them as the 'tigers' of the 'upper ten' (or 'upper ten thousand', a term coined in the early-nineteenth century to denote the wealthiest residents and ruling class in American and British cities). This newspaper went on to decry the Fijians' collective 'vanity' in spending wages on

${ }^{44}$ This is drawn from Kaushik Ghosh, 'A Market for Aboriginality: Primitivism and Race Classification in the Indentured Labour Market of Colonial India', in Subaltern Studies X: Writings on South Asian History and Society, eds Gautam Bhadra, Gyan Prakash and Susie Tharu (New Delhi: Oxford University Press, 1999), 14. See also Martinez et al, Colonialism and Male Domestic Service.

${ }^{45}$ Banivanua Mar, Violence and Colonial Dialogue, 41.

${ }^{46}$ New Zealand Times, 30 September 1880, 2.

${ }^{47}$ For a critique of the 'sheltered, sedentary view of late-19th-century Fijians', see Sudesh Mishra, 'The Leonidas Fijians: A Minor History', Journal of Pacific History 49, no. 3 (2014): 283-300. 
western finery, including clothing and portrait photography - a mere 'veneer' of civilisation under which lay dormant 'the elements of savagery and deviltry' ${ }^{48}$ A criminal act of murder was thereby closely yoked to the 'affront' of economic independence and social freedoms, and the basis to insist upon heightened settler surveillance and control.

A number of the Fijian men were 'very much annoyed' Joe was described as their kinsman - not to join in his denunciation, but to protest that this singular act was used to condemn a community unconnected to it. They each contributed a week's wages to a relief fund for the European victims. ${ }^{49}$ Through an interpreter they related that while they had been 'slaves' in Fiji, in Auckland they were 'freemen and gentlemen', yet after this incident they struggled to find work. ${ }^{50}$ In their public challenge to the presumed moral gulf between Islanders and Europeans and the idea that they were urgent targets of settler anxiety, the Fijian donors asserted their rightful participation in colonial civic life. Their collective action contrasted with the atomised position of Joe, who it appears had no social networks to draw on. He was convicted for murder, his sentence commuted by reason of insanity to penal servitude for life. Joe passed away a few years later in an asylum in Auckland. ${ }^{51}$

The prospect of any systematic recruitment of domestic workers from the neighbouring islands seemed unlikely given the attitudes revealed in response to this case. Yet men continued to move between the colonies in the service of their island-based employers. Fiji's officials looked with increasing disfavour on servants leaving Fiji to minister to people normally resident in the settler colonies. Thus they rejected an application

48 'Auckland (From our own correspondent)', Otago Daily Times, 9 October 1880, 3

${ }^{49}$ Grey River Argus, 27 October 1880, 2; West Coast Times, 27 October 1880, 2; Observer, 21 May $1881,387$.

${ }^{50}$ New Zealand Herald, 26 October 1880, 4; Otago Daily Times, 6 November 1880, 1. 51 'Official Visit to the Lunatic Asylum', New Zealand Herald, 4 January 1888, 6. 
by William Scott in 1885 to bring his indentured servant 'Kalman' to Sydney for twelve months to look after his two boys. ${ }^{52}$ But exceptions were also made, and I now turn to examine instances from the late 1890s where Indian, rather than Islander, men arrived in New Zealand from Fiji to work as domestic servants. Here, as in Joe's case, the stresses and frictions of displacement were stark, but public controversy and opposition centred more readily on employer abuse and the nature of the labour contract.

\section{Contested hierarchies: Indian domestic servants in New Zealand}

As Tony Ballantyne has argued, India was woven into the fabric of colonial cultural life in New Zealand in the second half of the nineteenth century, through traffic in commodities and ideas as well as 'surprisingly strong migration networks'. Many prominent men in intellectual and political circles arrived in New Zealand after careers in India, for the colony was 'an attractive proposition' for those seeking further advancement or comfortable retirement. ${ }^{53}$ Many of them transplanted a particular culture of domestic service, as well as wider notions about the value of 'coolie' labour.

This pattern was first established in colonial Australia. Lachlan Macquarie, appointed governor to New South Wales in 1810 after two decades in India, was accompanied by a Hindu servant, a former slave named George Jarvis. ${ }^{54}$ By the 1830 s and 1840 s, the figure of

${ }^{52}$ William Scott to Anson, and subsequent correspondence, 15 January 1885, CSO, 85.257, NAF.

${ }^{53}$ Tony Ballantyne, Webs of Empire: Locating New Zealand's Colonial Past (Wellington: Bridget Williams Books, 2012), 38-9.

${ }^{54}$ Robin Walsh, 'Jarvis, George (1790-1825)', Australian Dictionary of Biography, National Centre of Biography, Australian National University, http://adb.anu.edu.au/biography/jarvisgeorge-13005/text23509, published first in hardcopy 2005, accessed online 16 July 2017. 
the 'old Indian hand' influenced other settlers to agitate for the importation of 'coolie' labour. There was a different register here when later compared to New Zealand, in that these demands were linked to actual or feared loss of convict labour. ${ }^{55}$ Such proposals garnered little official support and were stymied by restrictions in British India that prevented Indian emigration, although some families brought large retinues of servants with them, such as the Morley family who arrived in Albany from Bombay in 1835 with twelve Indian servants. ${ }^{56}$ In one of the more prominent examples in New Zealand, John Cracroft Wilson, a judge at Moradabad in Utter Pradesh, visited New Zealand in 1853 during a leave of absence from the Indian Civil Service. He established an estate called Cashmere, now a suburb of Christchurch. After a stint back in India, including during the great revolt of 1857, he retired to Cashmere in 1859 , bringing with him a complement of seventeen servants (one of whom would later be interviewed in 1899 at the apparent age of 107). ${ }^{57}$ Upon entering parliament in

${ }^{55}$ Alan Dwight, 'The Use of Indian Labourers in New South Wales', Journal of the Royal Australian Historical Society 62, no. 2 (1976): 115-16, 122.

${ }^{56}$ Joyce Westrip and Peggy Holroyde, Colonial Cousins: A Surprising History of Connections between India and Australia (Kent Town: Wakefield Press, 2010), 125; see also Jessie Serle, 'Asian and Pacific Influences in Australian Domestic Interiors, 1788-1914,' Fabrications 4, no.1 (1993): 65-67.

${ }^{57}$ Tessa Kristiansen, 'Wilson, John Cracroft', first published in the Dictionary of New Zealand Biography, vol. 1, 1990, and updated online in May, 2002. Te Ara - the Encyclopedia of New Zealand, https://teara.govt.nz/en/biographies/1w31/wilson-john-

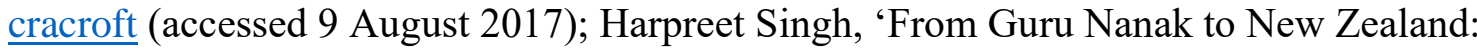
Mobility in the Sikh Tradition and the History of the Sikh Community in New Zealand to 1947 (PhD thesis, University of Otago, 2016), 70-71; Jacqueline Leckie, Indian Settlers: The 
New Zealand, Cracroft Wilson would advocate for the importation of Gurkah troops to suppress Māori resistance during the 1860s, which he promoted partly on the grounds of economy (their salaries were one-seventh of other colonial troops). ${ }^{58}$ One opponent denounced this inclination for 'cheap labour', and asserting he spoke on behalf of 'all true colonists', concluded crudely that there were 'too many darkies here already', objections to non-white immigration that would only intensify in New Zealand over the following decades. $^{59}$

Yet for many settlers, Fiji would come to serve as a more proximate zone of engagement with such labour questions and the status of Indian people in empire more generally. It was through Fiji and via routine networks of intra-colonial exchange, rather than British India itself, that settlers variously aspired to, as well as pushed back against, 'old' imperial models of master-servant relations. Impressions of daily life in Fiji, including the plantation labour trade and household management, were serialised in columns in the settler press, such as 'Life in Fiji' or 'Our Fiji Letter', circuits of information that together with visits of employers and their servants to New Zealand, arguably normalised impressions or reinforced anxieties of an accessible pool of domestic servants in Fiji. Travel accounts, facilitated by the monthly shipping schedules, a nascent cruise tourism trade, and the conjoining of New Zealand and Fiji in wider transpacific networks also encouraged

Story of a New Zealand South Asian Community (Dunedin: Otago University Press, 2007), 21-22; Otago Daily Times, 2 May 1899, 8.

58 'The Ghoorkas', Australasian, 23 January 1869, 8; New Zealand Parliamentary Debates (NZPD), vol. 6, 10-11 August (Wellington: 1869), 241- ; 366-89; 406-410; 615-41.

${ }^{59}$ Hawke's Bay Herald, 18 June 1869, 3. 
transcolonial familiarity. ${ }^{60}$ In one such account, Thomas Eykyn, an episcopal clergyman who spent six years in Queensland, New Zealand, Fiji and Hawai'i, stressed that 'none can tell the comfort of coloured servants except those who have been blessed with them'. Eykyn reached this conclusion in part having spent Christmas with an English family in Suva, whose servants were Indian 'but everything else English', while in the streets 'fleet-footed Indian servants, in bright liveries, are seen running on their masters' business ${ }^{61}$ His impressions communicated that racialised labour hierarchies served to undergird, if not augment, English authority and did not index the sort of 'moral decay' that proponents of white men's countries increasingly associated with race mixing in the proximate tropics, and, as I go on to discuss, could not countenance on home soil. ${ }^{62}$

It appears that a small number of Europeans in New Zealand were receptive to accounts like Eykyn's. In February 1898 George and Catherine Wilson travelled to Suva hoping to engage two free Indian men (i.e. time-expired plantation workers) for a two-year term at 30/- per month, to rise eventually to 40/- , along with food, clothing, board, medical care and a return passage to Suva. The Wilsons had emigrated to Palmerston North from Scotland six years earlier, but without any personal experience of the 'oriental' empire. Fiji officials approved their application, and they engaged a man named Mohabir, who was nineteen years old and resident in Fiji for ten years, and eighteen-year-old Louis Jethna, who had arrived in Fiji as a four-year-old orphan after his mother died on the voyage from India.

${ }^{60}$ For example, 'The Fiji Islands, Their Sugar Plantations, Coloured Labour, and Interesting Features, by a Recent Visitor', Otago Daily Times, 30 April 1892, 5.

${ }^{61}$ Thomas Eykyn [Peripatetic Parson], Parts of the Pacific (London: Swann Sonnenschein \& Co., 1896), 182, 275.

${ }^{62}$ Julia Martinez, 'Asian Servants for the Imperial Telegraph: Imagining North Australia as an Indian Ocean Colony before 1914', Australian Historical Studies 48, no. 2 (2017): 237. 
Within a few weeks of their employment in Palmerston North, Mohabir and Jethna complained of ill-treatment. They left the Wilsons' home and travelled to Wellington with the intention of earning enough money to return to Fiji. George Wilson had them arrested for stealing the clothes he had supplied them under the terms of their agreement. Knowing that he had no chance of succeeding in court, Wilson withdrew the charge and Mohabir, but not Jethna, was induced to return to work. Two days later Catherine Wilson assaulted Mohabir while he was chopping wood, whipping him across his head and body. He fled to the nearby township, where a chemist inspected his injuries and would later attest at her trial for assault. A police sergeant also recalled in court that Mohabir was 'crying and so cold that he could hardly speak'. While the court 'considered that an assault had been committed', it concluded it was 'of so trivial a nature' to justify dismissing the case. The trouble, the Bench argued, 'had occurred through importing cheap labour and the Government should put a stop to it' ${ }^{63}$

Undeterred, in August 1898 the Wilsons returned to Fiji to procure a new group of servants. Reports of Catherine Wilson's assault had reached the colony (possibly through the press, although George Wilson later accused a 'Wesleyan Parson' of passing on information to officials), ${ }^{64}$ and this, along with other impediments, including the absence of the governor whose permission was now required to take non-Europeans out of the colony, stalled the recruitment process. The Wilsons left Fiji to return in November, when they faced new objections as they had not secured the safe return of the men first indentured to them. Jethna and Mohabir had gone on to find other work - Jethna as a cook for a dairy farmer at Rata, and Mohabir as a domestic servant for a lawyer's widow. Catherine attested that while

\footnotetext{
${ }^{63}$ unidentified newspaper cutting enclosed in 98.979, CSO, NAF.

${ }^{64}$ George Wilson to Governor of Fiji, 28 November 1898, 98.979, CSO, NAF.
} 
Mohabir had agreed to return to Fiji with her, he did not honour their prior appointment and she left without him. ${ }^{65}$

Deliberations in Fiji turned on gauging the popular mood in New Zealand and the likely welfare of the servants upon leaving the colony. Officials were divided. The colonial secretary stressed that while ordinary residents might take servants with them during overseas travel, it was 'undesirable' for immigrants to go as domestics to colonies 'where their employment is generally looked upon with disfavour' ${ }^{66}$ Others argued that the expense of procuring servants 'was some security for good treatment', and it was 'patent' that courts of law were 'easily accessible to servants', thereby placing the regulatory burden onto the workers themselves. ${ }^{67}$ The Wilsons were eventually approved in January 1899 on the grounds that 'if the venture turns out badly' Fiji's officials would then have 'sufficient grounds' for refusing such applicants in the future. ${ }^{68}$ There is no indication that officials related to the new recruits - Ramjan, Kisri, and a fifteen-year-old boy, Ramgolan - anything of the experiences of Mohabir and Jethna while in the Wilsons' employ.

Even by the 1880 s, decades earlier than established in previous scholarship, Indians residing in New Zealand were engaging with local institutions, rather than merely existing 'on the periphery of colonial life'. They wrote to newspapers and appeared in court, activities that often entailed challenging negative portrayals of their communities, as Harpreet Singh has recently demonstrated. ${ }^{69}$ These observations would be borne out again in Palmerston North. Ramjan, Kisri and Ramgolan signed on to the Wilsons for a twelve-month term under

\footnotetext{
652 November 1898, 98.979, CSO, NAF.

6620 January 1899, 98.979, CSO, NAF.

679 December 1898, 98.979, CSO, NAF.

${ }^{68} 21$ January 1899, 98.979, CSO, NAF.

${ }^{69}$ Singh, 'From Guru Nanak to New Zealand', 75-6.
} 
the usual conditions. Within a fortnight Kisri was confined to bed unwell, yet Wilson refused to give him time off. When he failed to carry out instructions to move a basin from one room to another and to prepare lunch, Wilson dismissed him. Stranded with no pay, Kisri took a case of wrongful dismissal and arrears of wages to the Wanganui District Court. It is not clear how he came to engage the services of solicitor James Petrie Innes, who acted for Mohabir the previous year, though he may have been assisted by the Wilsons' former groomsman, Thomas Hastings, who would give evidence at the trial.

The servants routinely worked from 6am to $10 \mathrm{pm}$, Hastings related, and had complained the house 'was no better than a gaol'. Indeed, Catherine remarked to Hastings that the men should 'be chained up like dogs at night and let loose in the morning to do their work'. She demanded he thrash Kisri within the concealed stable grounds, and then bribed Hastings not to disclose this in court. In her testimony Catherine argued that she had had many servants in the past, including 'white, black and yellow', and could easily hire anyone in Palmerton North at short notice, yet others attested privately that 'no European servant would stay at their house' ${ }^{70}$ For his part, George Wilson argued that he never wished to get rid of Kisri, but only to frighten him to make him obedient in the future (and had offered to reemploy him a few days later) - an open admission of the failure of his patriarchal authority. Yet Kisri had insisted he would 'rather die in the bush' than return to work for the Wilsons. ${ }^{71}$ The trial recovered $£ 25$ damages and costs from Wilson, while a second trial fixed the damages at $£ 10$. The judge refused a third trial, and Wilson appealed the case in the (then) Supreme Court in February 1900, where Chief Justice Sir Robert Stout stressed that it could

\footnotetext{
${ }^{70}$ J.P. Innes to John Langford, Stipendiary Magistrate Suva, 29 March 1899, 98.979, CSO, NAF.
}

71 ‘Kisri v. Dr Wilson', Manawatu Evening Standard, 2 June 1899, enclosed in 98.979, CSO, NAF. 
not be contended 'that the servant was bound to return and run the risk of a thrashing'. ${ }^{72}$ Wilson was ultimately ordered to pay $£ 2415 \mathrm{~s} 6 \mathrm{~d}$ costs in addition to the original $£ 10$ damages. $^{73}$

In India itself, employer violence towards servants was seldom condemned, as Fae Dussart has argued, but regarded as necessary to ensure they performed the required work. She suggests that male servants were not easily positioned as vulnerable (in contrast to young, female domestics in England in the same period) ${ }^{74}$ In New Zealand, the men's status as very recent immigrants and their lack of community networks certainly made them more vulnerable. In similar ways to Indian domestic servants in Natal, the 'sense of displacement' following immigration had the 'greatest impact' over the servant-employer relationship. ${ }^{75}$ This dynamic was arguably starker in New Zealand than in Suva itself, where servants had informal opportunities to mix with one another, and where impressions of particular employers or labour conditions undoubtedly passed between them. In New Zealand, as Kisri, who could hardly speak English, said in court, he was lonely 'and no one was his friend'. ${ }^{76}$

${ }^{72}$ Evening Post, 22 February 1900, 6; Press, 22 February 1900, 5; New Zealand Law Reports, Wilson v. Kisri, 1900, vol. XVIII, 807-819 (quote is from 817).

${ }^{73}$ Manawatu Standard, 12 April 1900, 2.

${ }^{74}$ Fae Dussart, “"Strictly Legal Means”: Assault, Abuse and the Limits of Acceptable Behaviour in the Servant-Employer Relationship in Metropole and Colony, 1850-1890', in Colonization and Domestic Service, 167.

${ }^{75}$ Prinisha Badassay, ““And My Blood Became Hot!” Crimes of Passion, Crimes of Reason: An Analysis of the Crimes of Murder and Physical Assault Against Masters and Mistresses by their Indian Domestic Servants, Natal, 1880-1920', Journal of Natal and Zulu History 23 (2005): 71.

${ }^{76}$ Manawatu Evening Standard, 1 June 1899, enclosed in 98.979, CSO, NAF. 
Kisri's case sparked community debate, with a local newspaper, the Manawatu Standard, demanding the state intervene in what was framed as a wider problem:

It comes somewhat as a surprise that residents of this colony are able to go the islands and engage coloured labour on conditions which practically places natives at the mercy of their employers. If traffic in human flesh of this sort is to be allowed, the Legislature must set up safeguards of a very strict nature in the interests of the weaker party to the contract, especially as the case under notice is not the only one of the kind in this district. ${ }^{77}$

Wilson brought a libel case against the paper, arguing that it presented him as having 'meanly and nefariously traded or trafficked in Polynesian natives and labour to the great scandal of the community’. He sought $£ 501$ damages. ${ }^{78}$ The newspaper's proprietors, David and Frederick Pirani (also represented by Innes), argued that they presented 'fair and impartial' comments on the general question of engaging labour, published for the public benefit. Wilson was awarded $£ 100$. The Pirani brothers believed that few people in the district would agree, and went on to argue that the case illuminated the racial limits of community belonging: imported workers competed with white labour (even as white men would not consider domestic service), and such schemes allowed 'Indians at large to recover compensation under the tedious process of the law', thereby anticipating growing resistance across the empire to anxieties about Indians increasingly demanding their rights, including

\footnotetext{
${ }^{77}$ Manawatu Standard, 7 April 1900, 3.

${ }^{78}$ Wanganui Chronicle, 7 April 1900, 2.
} 
later more broadly of imperial citizenship. ${ }^{79}$ The newspaper published donations towards its legal costs under pseudonyms such as 'Sympathiser', 'An Admirer' and 'Straightforward'. 80

At the same time, the broader constitutional relationship between New Zealand and Fiji came under the spotlight with New Zealand Premier Richard Seddon's advocacy from 1900 for the federation of the two colonies, an extended debate which turned keenly on questions of race, labour and colonial difference. ${ }^{81}$ His proposal revived earlier agitation from the mid-1880s, but was also was sparked by the British loss of the Samoan islands following their imperial partition between Germany and the United States in 1899. Feeling deeply aggrieved, Seddon aimed to assume the mantle of British responsibility for other islands in the Pacific. His ambitions were multi-faceted, but rested on security, trade and prestige, especially in the face of a looming Australian federation. Seddon's interest in Fiji was further cemented after a visit to Suva, where he became enamoured of a vocal group of disaffected white settlers who protested over their limited constitutional rights under Crown Colony rule. Seddon believed they deserved assistance to obtain responsible government, not least because many of them were New Zealanders and had previously 'enjoyed freedom'. ${ }^{82}$ While the Colonial Office rejected his demands, Seddon did not accept defeat and continued to agitate for internal reform in Fiji, in the belief that federation with New Zealand would follow in the wake of constitutional change. ${ }^{83}$

\footnotetext{
${ }^{79}$ Manawatu Standard, 7 April 1900, 2.

${ }^{80}$ Manawatu Standard, 14 April 1900, 2

${ }^{81}$ Angus Ross, New Zealand Aspirations in the Pacific in the Nineteenth Century (Oxford:
} Clarendon Press, 1964), 157-60; 271-80.

${ }^{82}$ NZPD, vol. 115 (1900), 473.

${ }^{83}$ D. K. Fieldhouse, 'New Zealand, Fiji and the Colonial Office, 1900-1902', Historical Studies: Australia and New Zealand 8, no. 30 (1958): 118, 122. 
Perceptions and anxieties about the circulation of Indian and other colonial labour underpinned domestic opposition to New Zealand's Pacific imperial ambitions. Leader of the opposition, Captain William Russell, held that the incorporation of Fiji 'means a colouredlabour problem of great intricacy', arguing that planters would object if New Zealand imposed restrictions on Indian indenture. Although he acknowledged that Seddon did not entertain the prospect of 'coloured' labour freely entering New Zealand (and Seddon himself introduced bills in the 1890s that aimed to restrict the entry of Indians), ${ }^{84}$ the key question 'must be the labour one'. Federation would mean New Zealand tolerating 'coolie' labour within its realm in order to ensure Fiji's prosperous future. ${ }^{85}$ Indenture schemes from India permitted labourers to go only to certain islands, and Seddon asserted (inaccurately) that receiving colonies were required to return them 'when called upon to do so by the Indian Government'. He thereby sought to sequester or sideline the 'coolie question' from the envisioning of future relations between New Zealand and Fiji, reinforcing notions that Indian workers might be moved around the empire but not in ways to be determined by them. ${ }^{86}$

Returning to the controversies at the heart of the Wilsons' preference for hiring servants from Fiji, responses in the courts and the press turned not only on the workers' race, but also the image of the white master or mistress wielding absolute authority. Macdonald points to the premium placed in New Zealand on the avoidance of 'dark servility';

${ }^{84}$ Including the failed 1896 Asiatic Restriction Bill. See Leckie, Indian Settlers, 73. ${ }^{85}$ NZPD, vol. 115 (1900), 479, 480.

${ }^{86}$ NZPD, vol. 115 (1900), 495. See also Merze Tate and Fidele Foy, 'Slavery and Racism in South Pacific Annexations', Journal of Negro History 50, no. 1 (1965): 18-20; Nicholas Hoare, 'New Zealand's "Critics of Empire”: Domestic Opposition to New Zealand's Pacific Empire, 1883-1948' (MA Thesis, Victoria University of Wellington, 2014), 23-28. 
conversely, this also entailed rejecting autocratic white mastery. ${ }^{87}$ Here, again in contrast to debates about domestic service relations in India, the 'maintenance of colonial prestige' rested not on upholding the 'legitimate authority' of the master, as Dussart has argued, for the Wilsons' actions were increasingly cast as out of step with mainstream opinion. ${ }^{88}$ Rather, it rested on championing the cause, dignity and self-possession of white labour, supported in the home by white women (usually one's kin), and rejecting settler recourse to imported and subordinate colonial workers.

In all of this it is difficult to account for the Wilsons' repeated abusive behaviour and sense of entitlement. It would be too crude to state they were simply acting in accord with accepted norms of a tropical colony. There is little in my sources to suggest that physical force was a structural feature of domestic service in colonial Fiji, though reports of violence were not unheard of. ${ }^{89}$ On the other hand significant affective bonds might develop in the context of hierarchical relations, as Rodney Acraman was later proud to record. ${ }^{90}$ In any case, a number of the men had worked as servants in Fiji, and they quickly found conditions in the Wilsons' home intolerable. Perhaps the Wilsons fashioned themselves as members of the colonial elite, for they lived in a large house set in extensive grounds, and a complement of Indian servants may have completed the display in their eyes. ${ }^{91}$ But it is still hard to fathom

\footnotetext{
${ }^{87}$ Macdonald, 'Why Was There No Answer to the "Servant Problem”?' 23.

${ }^{88}$ Dussart, "“Strictly Legal Means”, 167.

${ }^{89}$ Rumours circulated in India that Udal threatened Ruzzak with a gun, 91.3623, CSO, NAF.

${ }^{90} \mathrm{He}$ also noted that when an elderly Indian servant of his uncle died, he was buried in the family cemetery. PMB Audio 26-7, Rodney Acraman (9 March 1999).

${ }^{91}$ Elitism also underpinned the employment of Chinese servants in northern Australia, see Claire Lowrie, "White "Men" and Their Chinese "Boys": Sexuality, Masculinity and Colonial Power in Singapore and Darwin, 1880s to 1930s', History Australia 10, no. 1 (2013): 35-57.
} 
why they so quickly alienated the people they went to such trouble to recruit. George Wilson attempted on two further occasions to persuade Fijian officials to release men, but was refused on the basis 'there was so much trouble' surrounding his previous engagements, including wrongful dismissal, assault and failure to return men at the appointed time. The final obstacle lay in New Zealand's objections to the introduction 'of these coloured servants' ${ }^{92}$ The Wilsons finally resigned themselves to local recruitment, when in 1904 Catherine placed an advertisement for 'two lady helps. All domestic duties', a more appropriately gendered aspiration. ${ }^{93}$ Yet in 1926 (and now a widow) she sought a 'Gardener, Chinese or Japanese', suggestive of lingering notions of racial power encoded in service relations. ${ }^{94}$

Approvals were still granted in Fiji to white residents travelling with servants to New Zealand for periods of up to twelve months. Servants gained entry if they passed the Englishlanguage test under the terms of the 1899 Immigration Restriction Act. ${ }^{95}$ This did not appear to rest on a consistent application of policy, but rather on assessments of the 'character' of the applicant or the whim of the official. A request by Hugh Keith for a gardener to accompany him for one year was denied on the grounds that New Zealand 'discourages the introduction

9217 June 1903 and 25 June 1903. 03.2230, CSO, NAF.

${ }^{93}$ Manawatu Times, 29 August 1904, 1.

94 'Situations Vacant', Manawatu Times, 28 August 1926, 2. George Wilson died suddenly in 1913 at the age of forty-eight. Catherine left his office and personal effects untouched as a sort of shrine in his memory until her own death twenty years later. 'Death of Recluse', New Zealand Herald, 12 January 1935, 13.

${ }^{95}$ For examples of approval for entry for six and twelve-month terms, see Box 114, 1909/1106 and 1909/1121, BBAO A133 5544; Box 100, 1907/2236, BBAO A78 5544, Customs Service Auckland Office, National Archives of New Zealand. 
of this class of labour'. ${ }^{96}$ Yet three months later, A.D. Carr who wished to take an orphaned Indian girl with him to New Zealand for six months was approved, as he was a 'hardworking and successful banana planter'. ${ }^{97}$ Nor was the governor's consent always sought as required by law, the colonial secretary noting he had on occasion let people through without it. ${ }^{98}$ Servants' experiences once in New Zealand also varied considerably. Unlike the curtailed freedoms of the men employed at the Wilsons, Mawa, the Indian servant of a Suva dentist who spent six months in Auckland in 1900, attended night school and reportedly became 'quite a good scholar'. 99

Indian migrants who mobilised family networks as part of a global diaspora separate from indenture began to arrive in New Zealand from the last decades of the nineteenth century, and aimed to establish independent livelihoods. The circumstances of the servants' arrival from Fiji cast them in a different light; they seldom moved autonomously, but rather together with their employers or in order to fulfil contractual obligations to them. The 'colonial difference' of Indians was not marked simply by race. What became of these men after leaving the Wilsons' employment? Louis Jethna, one of the first two servants, worked as a cook for a dairy farmer, John Hammond. Jethna and the daughter of a neighbouring family fell in love, but her father refused to permit their marriage. Jethna reportedly 'fell into melancholy' and shortly thereafter ended his own life. An inquest attributed his suicide by gunshot wound to 'unsound mind'. Unlike newspaper reports of his death, the inquest also disclosed Jethna and the European woman had a child together. Jethna died destitute, his only possessions a horse bridle and saddle. Anxious to give him a decent burial, Hammond paid

\footnotetext{
${ }^{96} 15$ February 1901, 01.667, CSO, NAF.

${ }^{97} 6$ May 1901 and 7 May 1901, 01.1906, CSO, NAF.

${ }^{98} 5$ September 1900, 00.3348, CSO, NAF.

${ }^{99} 21$ November 1900, 00.3348, CSO, NAF.
} 
the funeral expenses. Although marriages between Indian men and white women were not unknown in the early-twentieth century, the construct of Indian men as a 'generalised threat to progressive settler culture' dominated political discourse at the turn of the century, extended to the domestic realm, perhaps in this instance hardening racial opposition to a desired legal union. ${ }^{100}$ At the same time in Fiji, notions of skill, dignity and efficiency placed Indian men at the highest rung of the service hierarchy. Claims that Indian male servants posed a sexual threat or aroused anxieties about racial contamination within the home were seldom publicly made. The practice of referring to adult employees as 'boys' may also arguably point to how employers chose to regard the sexual agency of their servants. ${ }^{101}$

Like Mohabir and Jethna, Kisri and Ramgolan went on to find other employment, Kisri as a cook in a local hotel and Ramgolan as a school teacher's servant. Both men expressed a desire to return to Fiji, but it appears that neither ultimately did. It might be possible that Kisri later followed Ramgolan and Ramjan to Auckland and was the same 'James Kisri' recorded in 1902 as an Auckland shopowner. By 1917, James Kisri was a storekeeper in Waimiha, a small central North Island town, and ten years later was trading as

${ }^{100}$ Ballantyne, Webs of Empire, 101, see 98-104; Leckie notes that the 1926 Census recorded 30 per cent of the Indian population in New Zealand were of mixed descent, see Indian Settlers, 65. For a discussion of racial and sexual relationships involving South Asian workers on the US West Coast, see Nayan Shah, Stranger Intimacy: Contesting Race, Sexuality and the Law in the North American West (Berkeley: University of California Press, 2012).

${ }^{101}$ Similar themes are discussed throughout Martinez et al., Colonialism and Male Domestic Service. 
Natali and Kisri Ltd. ${ }^{102}$ Like many Indian migrants, his business partner, Jelal Kalyanji Natali (whose father adopted the surname after emigrating to Natal from Gujarat), took up menial service roles (he worked in a hotel kitchen) before pursing self-employment. ${ }^{103}$ In 1915 Ramgolan was working as a cook in Wellington. During World War I, both Kisri and Ramoglan were named in enlistment rolls alongside Europeans (with Ramgolan one of a long list of 'missing reservists' who failed to appear for their medical examination), indicating that they had risen above the colonial relationship that originally facilitated their entry to New Zealand. ${ }^{104}$

Yet despite this, political resistance to the entry of Indians hardened in New Zealand in the first decades of the twentieth century, with fears many entered the colony via Fiji at the expiration of their indenture contracts, and helped by 'cram schools' in Suva set up to train them to memorise the text required to enter the country. ${ }^{105}$ It was only the exigencies of war that prevented the introduction in 1914 of a tougher language test in New Zealand, designed

${ }^{102}$ New Zealand Herald, 27 August 1902; Wanganui Chronicle, 4 September 1917, 6; Auckland Star, 22 September 1927, 4.

${ }^{103}$ Natali would become a prominent spokesperson for the Indian community in New Zealand, see Jacqueline Leckie, 'Natali, Jelal Kalyanji', first published in the Dictionary of New Zealand Biography, vol. 5, 2000. Te Ara - the Encyclopedia of New Zealand, https://teara.govt.nz/en/biographies/5n1/natali-jelal-kalyanji (accessed 6 August 2017). ${ }^{104}$ Evening Post, 2 October 1917, 10; Wanganui Chronicle, 4 September 1917, 6; 'Missing Reservists', Dominion, 30 March 1918, 9.

105 P.S. O'Connor, 'Keeping New Zealand White, 1908-1920', New Zealand Journal of History 2, no. 1 (1968): 46; Leckie Indian Settlers, 27. See also, Sekhar Bandyopadhyay 'A History of Small Numbers: Indians in New Zealand, c.1890s-1930s', New Zealand Journal of History 43, no. 2 (2009): 150-68. 
to exclude Indians. Immigration for Indians remained relatively open until the 1920 Immigration Restriction Amendment Act introduced a permit system. ${ }^{106}$ In Australia, similar legislative barriers prompted exemption requests to import Asian domestic labour, justified, paradoxically enough, as the only way to achieve the goal of white settlement in the tropics. $^{107}$

\section{Between Fiji and New Zealand}

In 1909, Dyson Blair, Fiji's Commissioner of Lands, took a three-month tour of New Zealand with his wife, child, and an Indian servant, Behari, principally to investigate New Zealand's mining laws and other economic developments. Widespread public interest in his visit meant that he instead ended up explaining Fiji wherever he went, including taking pains to quash rumours of an imminent Indian uprising in Fiji as 'utter nonsense'. ${ }^{108}$ Blair used Behari's status to draw attention to the divergent position of Indians across the British Pacific, as he 'laughingly explained how different New Zealand Asiatic laws were to Fijian laws': 'When

${ }^{106}$ For closer engagement with the bureaucratic mechanisms following the implementation of the 1920 Act, including the continued possibilities of entry for Anglo-Indians, see Jane McCabe, 'Working the Permit System: Anglo-Indian immigration to New Zealand, 19201940’, New Zealand Journal of History 48, no. 2 (2014): 27-49.

${ }^{107}$ B.W. Higman, 'Testing the Boundaries of White Australia: Domestic Servants and Immigration Policy, 1901-1945', Immigrants and Minorities 22, no. 1 (2003): 1-21. See Martinez, 'Asian Servants for the Imperial Telegraph'; Claire Lowrie, Masters and Servants: Cultures of Empire in the Tropics (Manchester: Manchester University Press, 2016); Russell McGregor, 'Drawing the Local Colour Line: White Australia and the Tropical North', Journal of Pacific History, 47, no. 3 (2012), 329-46.

${ }^{108}$ Inangahua Times, 12 February 1909, 2; Taranaki Herald, 13 February 1909, 8. 
he left Fiji he had to sign a $£ 50$ bond that he would bring the boy back, and when he landed in here he had to sign a $£ 100$ bond that he would take the Indian away from New Zealand with him'. ${ }^{109}$

Equally modes of surveillance and control, these divergent responses to non-white mobility across colonial terrain have come to characterise the distinctions between settler and 'other' colonial formations in the history of the Pacific. The former held little place for nonwhite imported labour, while the latter depended upon it. They also help to explain the contrasts Rodney Acraman drew between domestic life in New Zealand and Fiji some four decades later, with servants 'at home' in one place but not the other. In this article I have sought to recover some glimpses of individual lives that remind us that pathways to these divergent outcomes were not always absolute, that boundary marking was often incomplete, and that state controls to police colonial difference attempted to write out or over existing entanglements rather than necessarily seeking to pre-empt their possibility.

At the same time, our current histories do not accord much room for the in-between, temporary or short-term mobilities that continued to cross-cut imperial spaces. Emphasis on the late-nineteenth-century rise of racially restrictive immigration policies tends to privilege responses to perceived permanent arrivals and those who travelled independently, rather than in the intimate service of white employers, for instance. Whereas Macdonald pondered whether 'only lines of geography' and related questions of climate, separated the white settler housewife in New Zealand from the 'white lady' or 'white missus' in colonies such as Fiji, 110 the 'white missus' (and/or master) also travelled on occasion from Fiji to New Zealand accompanied by a non-white servant or two. They may have stayed for a few days, months or

109 'The Fiji Islands. Visit of the Commissioner of Lands', Hastings Standard, 12 March $1909,4$.

${ }^{110}$ Macdonald, 'Why Was There No Answer to the "Servant Problem”?' 9. 
perhaps a year, but they were highly visible in the communities they moved amongst. Such traffic was routine enough to encourage us to re-examine the nature of ongoing transcolonial mobilities in contexts where connections were increasingly channelled or controlled, but not unequivocally terminated or denied. Finally, whereas white settlers may have fashioned the colonial 'sisterhood' of Australasia, and the servants who accompanied them appeared only to underline Fiji's frictional status within it, it is necessary also to recognise the capacity and self-mobilisation of servants to challenge, protest and escape the bounds of colonial subordination that threaded through these connected worlds.

\section{Acknowledgements}

Research for this article was supported by the Australian Research Council (project DP110100490). I would like to thank audiences at the 'Colonial Economies, Violence and Intimacy' symposium, University of Tasmania, 10-11 November 2016 and the 'Colonial Formations' conference, University of Wollongong, 23-25 November 2016 for their questions and comments. Claire Lowrie, Julia Martínez, Sharon Crozier-de Rosa and Jane Carey provided valuable feedback. I am also grateful to the journal's anonymous reviewers for their suggestions and comments. 